\title{
Bacterial Lipoteichoic Acid Sensitizes Host Cells for Destruction by Autologous Complement
}

\author{
Donna S. Hummell and Jerry A. Winkelstein \\ Department of Pediatrics and Department of Molecular Biology and Genetics, The Johns Hopkins University \\ School of Medicine, Baltimore, Maryland 21205
}

\begin{abstract}
Lipoteichoic acids (LTA) released by gram-positive bacteria can spontaneously bind to mammalian cell surfaces. In the present study, erythrocytes (E) sensitized with pneumococcal LTA (LTAE) were used as a model system to determine if LTA could render host cells susceptible to damage by autologous complement. Complement (C)-mediated lysis of LTA-E from normal rats and normal humans occurred when these cells were incubated in their respective autologous sera in vitro. In addition, when LTA-E from a C2-deficient human and from C4-deficient guinea pigs were incubated in their autologous sera, there was significant lysis in vitro, demonstrating a role for the alternative pathway. The in vivo survival of ${ }^{51} \mathrm{Cr}$-labeled autologous $\mathrm{LTA}-\mathrm{E}$ was also studied. Only $2.9 \%$ of autologous LTA-E remained in the circulation of normal rats after $90 \mathrm{~min}$. In contrast, $31.2 \%$ of autologous LTA-E remained in the circulation of rats depleted of C3. Intravascular hemolysis accounted for the clearance of LTA$E$ in the normal rats, whereas liver sequestration was responsible for clearance in the $\mathrm{C} 3$-depleted rats. These results demonstrate that LTA can render the host's cells susceptible to damage by its own complement system, establishing this as a possible mechanism of tissue damage in natural bacterial infections.
\end{abstract}

\section{Introduction}

The membrane teichoic acids of gram-positive bacteria are amphiphilic polysaccharides covalently linked to a terminal glycolipid moiety; hence, the name lipoteichoic acid (LTA) ${ }^{1}$ (1). Whereas nascent LTA molecules are membrane-associated, many are subsequently released by the bacterium into the surrounding environment (2). Bacterial release of free LTA molecules has been shown to be dependent upon both time and tem-

Address reprint requests to Dr. Winkelstein, CMSC 1103, The Johns Hopkins Hospital, 600 N. Wolfe Street, Baltimore, MD 21205.

Received for publication 13 June 1985 and in revised form 7 January 1986.

1. Abbreviations used in this paper: CoVF, cobra venom factor, C2D HS, C2-deficient human serum; C4D GPS, C4-deficient guinea pig serum; E, erythrocyte(s); GPS, guinea pig serum; $\mathrm{GVB}^{++}$, veronal-buffered saline containing gelatin, calcium, and magnesium; GVB-EDTA, veronalbuffered saline containing gelatin and EDTA; GVB-Mg-EGTA, veronalbuffered saline containing gelatin, magnesium, and EGTA; LTA, lipoteichoic acid; LTA-E, erythrocytes sensitized with pneumococcal LTA; NHS, normal human serum; NRS, normal rat serum; $\mathrm{VBS}^{++}$, veronalbuffered saline with calcium and magnesium; VBS-EDTA, veronal-buffered saline containing EDTA.

J. Clin. Invest.

(c) The American Society for Clinical Investigation, Inc.

$0021-9738 / 86 / 05 / 1533 / 06 \$ 1.00$

Volume 77, May 1986, 1533-1538 perature (3), to be independent of cell division or cell decay (3), and to be favored by bacterial exposure to certain antibiotics $(3,4)$.

Certain characteristics of the LTA molecule may be of significance in the interaction of the bacterium and the host during infection. Through its terminal glycolipid moiety, an LTA molecule can bind to a variety of mammalian cells, including erythrocytes (5), platelets (6), lymphocytes (7), and buccal mucosal cells (8). This binding has been shown to be specific, reversible, and to a single population of receptors on the cell surface (58). Apparently, LTA on the surface of mammalian cells retains its antigenic specificity because these cells can be agglutinated by anti-LTA antibodies (9-12). Furthermore, erythrocytes bearing LTA on their surfaces will lyse when incubated in heterologous sera via activation of either the classical or alternative complement pathways (11-13).

The above data suggest that the host tissue damage that occurs during the course of a bacterial infection may in part be mediated by the host's complement system directed against its own cells bearing surface LTA. The present study explored this possibility using a model system in which erythrocytes from individual animals were sensitized with pneumococcal LTA and then either exposed to autologous serum in vitro or reinfused into the animal from which they were originally obtained. The results demonstrate that LTA can render the host's cells susceptible to damage by its own complement system, establishing this as a possible mechanism of tissue damage in natural bacterial infections.

\section{Methods}

Buffers. Veronal-buffered saline, $\mathrm{pH} 7.4$, with ionic strength 0.147 and containing $0.15 \mathrm{mM} \mathrm{Ca}^{++}$, and $1 \mathrm{mM} \mathrm{Mg}^{++}\left(\mathrm{VBS}^{++}\right)$, and an identical buffer containing $0.1 \%$ gelatin $\left(\mathrm{GVB}^{++}\right)$, were prepared as previously described (14). Veronal-buffered saline without $\mathrm{Ca}^{++}$or $\mathrm{Mg}^{++}$and containing $0.01 \mathrm{M}$ EDTA was also prepared with $0.1 \%$ gelatin (GVB-EDTA) and without gelatin (VBS-EDTA). In some experiments, rat serum was diluted in veronal-buffered saline containing $0.1 \%$ gelatin, $3 \mathrm{mM} \mathrm{Mg}^{++}$, and 15 mM EGTA (15), and human serum was diluted in veronalbuffered saline containing $0.1 \%$ gelatin, $10 \mathrm{mM} \mathrm{Mg}^{++}$, and $10 \mathrm{mM}$ EGTA (16) (GVB-Mg-EGTA).

Animals. Male Sprague-Dawley rats, 35-42 d of age and weighing 150-200 g, were obtained from Harlan Sprague Dawley, Walkersville, MD.

Cobra venom treatment of animals. In some experiments, rats were injected intraperitoneally with $300 \mathrm{U} / \mathrm{kg}$ of purified cobra venom factor (Naja naja) (CoVF) (Cordis Laboratories, Miami, FL) 24 and $4 \mathrm{~h}$ prior to reinfusion of their autologous erythrocytes. All animals had $<5 \%$ of the normal control level of functional $\mathrm{C} 3$ activity (17) at the time of the erythrocyte survival studies.

Sera. Serum was obtained from individual normal rats (NRS) by cardiac puncture. Complement was inactivated in some aliquots of rat serum by incubation with $50 \mathrm{U} / \mathrm{ml}$ of CoVF for $1 \mathrm{~h}$ at $37^{\circ} \mathrm{C}$. Serum treated with CoVF had $<4 \%$ of the normal control level of functional 
C3 activity (17). Guinea pig serum deficient in the fourth component of complement (C4) was obtained from individual animals with a genetically determined complete deficiency of C4 (C4D GPS) (18). For reconstitution experiments, purified guinea pig C4 (Cordis Laboratories) was added to the C4D GPS to yield a final C4 concentration of $500 \mathrm{U} / \mathrm{ml}$. Human serum deficient in the second component of complement (C2) was obtained from a patient with an inherited complete deficiency of C2 (C2D HS) (19).

Normal guinea pig serum (GPS) was purchased from Pel-Freeze Biologicals, Rogers, AR. Prior to use as a complement source in the antiLTA antibody assays, GPS was incubated twice with sheep erythrocytes $\left(4 \times 10^{8} \mathrm{cells} / \mathrm{ml}\right)$ and twice with formalin-fixed $\mathrm{R} 36 \mathrm{~A}$ pneumococci $(2$ $\times 10^{10}$ organisms $/ \mathrm{ml}$ ) (20) for $1 \mathrm{~h}$ at $0^{\circ} \mathrm{C}$ to remove anti-sheep erythrocyte and anti-LTA antibodies.

Erythrocytes. Fresh erythrocytes (E) were drawn by cardiac puncture from individual C4-deficient guinea pigs and from individual rats into equal volumes of VBS-EDTA. E were also obtained from the C2-deficient patient and a normal human volunteer, transferred into a standard sterile EDTA blood tube, and stored at $4^{\circ} \mathrm{C}$ for no longer than $5 \mathrm{~d}$. All $\mathrm{E}$ preparations were washed three times in VBS-EDTA, twice in $\mathrm{VBS}^{++}$, and then standardized spectrophotometrically to $5.4 \times 10^{8} \mathrm{cell} / \mathrm{ml}$ of $\mathrm{VBS}^{++}$immediately before use.

Pneumococcal LTA. Purified LTA was prepared from an unencapsulated strain of pneumococcus, R36A, as described previously (12). Briefly, the pneumococci were grown in a chemically defined media (21), and the organisms were harvested by centrifugation and allowed to undergo autolysis. The resulting pellet was treated with trypsin at $37^{\circ} \mathrm{C}$ for $3 \mathrm{~d}$ and then defatted by sequential treatment with $95 \%$ acetone, ethanol-ether (3:1), and chloroform-methanol (1:1). The residue was then extracted with $\mathrm{H}_{2} \mathrm{O}$, and the extract was treated with deoxyribonuclease and ribonuclease and then precipitated with absolute ethanol. The resulting precipitate was extracted with $\mathrm{H}_{2} \mathrm{O}$, precipitated with acetone, redissolved in $\mathrm{H}_{2} \mathrm{O}$, and stored at $-70^{\circ} \mathrm{C}$.

In some instances, the pneumococci were grown in the presence of [ methyl $^{3} \mathrm{H}$ ]choline (New England Nuclear, Boston, MA) to radiolabel the LTA (22).

Quantitation of anti-LTA antibody. A hemolytic assay was used to measure serum anti-LTA antibody activity (14). Briefly, target sheep E at $1.5 \times 10^{8} / \mathrm{ml}$ of $\mathrm{VBS}^{++}$were incubated with either $20 \mu \mathrm{g} / \mathrm{ml}$ of purified pneumococcal LTA, or with buffer, for $1 \mathrm{~h}$ at $37^{\circ} \mathrm{C}$, washed once, and then resuspended to $1.5 \times 10^{8} / \mathrm{ml}$ in GVB-EDTA. Dilutions of test sera in GVB-EDTA were incubated with either the LTA-treated E (LTA-E) or buffer-treated $\mathrm{E}$ for $30 \mathrm{~min}$ at $37^{\circ} \mathrm{C}$, and the supernatants removed by centrifugation. Each $\mathrm{E}$ pellet was then resuspended in 5\% absorbed guinea pig complement in $\mathrm{GVB}^{++}$and incubated for $30 \mathrm{~min}$ at $37^{\circ} \mathrm{C}$, and the percent lysis was determined spectrophotometrically. Specific lysis for a given dilution of test serum was calculated by subtracting the percent lysis of the unsensitized E from that of the LTA-E. The result for each serum specimen was expressed as the $\mathrm{AH}_{50}$ (hemolytic antibody) titer, i.e., that dilution resulting in 50\% net specific lysis of the LTA-E.

In vitro complement activation. $\mathrm{E}$ at $5.4 \times 10^{8}$ cells $/ \mathrm{ml}$ of $\mathrm{VBS}^{++}$ were incubated at $37^{\circ} \mathrm{C}$ for $30 \mathrm{~min}$ with the desired concentration of LTA (LTA-E) or with $\mathrm{VBS}^{++}(\mathrm{E})$, and then washed three times in $\mathrm{GVB}^{++}$. The LTA-E were then incubated at a concentration of $4.5 \times 10^{7}$ cells/ $\mathrm{ml}$ with the desired concentration of autologous serum for $30 \mathrm{~min}$ at $37^{\circ} \mathrm{C}$. The percent lysis was measured spectrophotometrically, and the specific lysis calculated as described. Lysis of control unsensitized $\mathrm{E}$ never exceeded 3\%.

In vivo $E$ survival. Fresh $\mathrm{E}$ were obtained by cardiac puncture from individual rats, washed, and standardized to $5.4 \times 10^{8}$ cells $/ \mathrm{ml}$ of $\mathrm{VBS}^{++}$. Each specimen was then incubated with $25 \mu \mathrm{Ci} / \mathrm{ml}$ of ${ }^{51} \mathrm{Cr}$ sodium chromate (E. R. Squibb, Princeton, NJ) with frequent mixing in a water bath at $37^{\circ} \mathrm{C}$ for $30 \mathrm{~min}$. The chromated cells were washed once in $\mathrm{VBS}^{++}$, incubated for $2 \mathrm{~min}$ at room temperature with $2 \mathrm{mg} / \mathrm{ml}$ of ascorbic acid injection U.S.P. (Cevalin) (Eli Lilly \& Co., Indianapolis, IN), then washed and resuspended to $5.4 \times 10^{8} \mathrm{cell} / \mathrm{ml}$ of $\mathrm{VBS}^{++}$. Aliquots of the ${ }^{51} \mathrm{Cr}$ labeled $\mathrm{E}$ were then incubated with either LTA at $50 \mu \mathrm{g} / \mathrm{ml}$ of $\mathrm{VBS}^{++}$ (LTA-E) or with $\mathrm{VBS}^{++}$alone (E) at $37^{\circ} \mathrm{C}$ for $30 \mathrm{~min}$, washed once in
$\mathrm{GVB}^{++}$, and then resuspended to $5.4 \times 10^{8} \mathrm{cells} / \mathrm{ml}$ of $\mathrm{GVB}^{++}$. The incorporation of ${ }^{51} \mathrm{Cr}$ was determined by counting an aliquot of $\mathrm{E}$ in a Searle model 1195 automatic gamma counter (Amersham-Searle, Arlington Heights, IL). When either ${ }^{51} \mathrm{Cr}$-labeled LTA-E or ${ }^{51} \mathrm{Cr}$-labeled unsensitized $\mathrm{E}$ were incubated in $\mathrm{GVB}^{++}$at $37^{\circ} \mathrm{C}$ for $30 \mathrm{~min}$, the elution of free ${ }^{51} \mathrm{Cr}$ was found to be consistently $<5 \%$.

Aliquots of $0.5 \mathrm{ml}$ of the treated $\mathrm{E}$ from individual rats were injected into the dorsolateral tail veins of the animals from which they were originally obtained, and their circulatory survival was determined by the serial withdrawal of $0.1 \mathrm{ml}$ of blood from the tail veins of each animal. Each aliquot of blood was suspended in $0.1 \mathrm{ml}$ of VBS-EDTA, the plasma was separated by centrifugation, and the relative amounts of ${ }^{\text {s1 }} \mathrm{Cr}$ present in the $\mathrm{E}$ and plasma were determined. The percentage of predicted radioactivity was calculated based upon the dilution of the total injected counts per minute in an assumed circulating blood volume of $62 \mathrm{ml} / \mathrm{kg}$ for each animal (23).

Organ sequestration. In some experiments, rats were killed $30 \mathrm{~min}$ after reinfusion of their autologous ${ }^{51} \mathrm{Cr}$-labeled $\mathrm{E}$ and the liver, spleen, lungs, and kidneys of each animal were removed for whole organ counting.

\section{Results}

In vitro activation of autologous complement by LTA-E. Initial experiments were performed to determine whether pneumococcal LTA could sensitize rat E for in vitro lysis by autologous complement. When $\mathrm{E}$ from an individual rat were preincubated with increasing amounts of LTA, and then exposed to $50 \%$ autologous NRS, there was an increasing amount of lysis. Optimal lysis occurred at a concentration of $50 \mu \mathrm{g} / \mathrm{ml}$ of LTA (Fig. 1). No significant lysis was observed when optimally sensitized LTA$E$ were incubated in autologous serum that had been treated with $0.01 \mathrm{M}$ EDTA, with CoVF, or heated to $56^{\circ} \mathrm{C}$ for $1 \mathrm{~h}$. Increasing concentrations of autologous NRS in $\mathrm{GVB}^{++}$(Fig. 2) resulted in an increasing amount of lysis of rat $E$ preincubated with $50 \mu \mathrm{g} / \mathrm{ml}$ LTA, with maximal lysis observed when $20-50 \%$ autologous NRS was used.

Experiments were then conducted to determine whether LTA-E could by lysed in autologous serum via activation of the alternative pathway. No lysis was observed when $\mathrm{E}$ from an individual rat were optimally sensitized with $50 \mu \mathrm{g} / \mathrm{ml}$ LTA, and then incubated in 50\% autologous NRS diluted in GVBMg-EDTA to block activation of the classical pathway (Table I). In contrast, incubation of the same cells in 50\% autologous

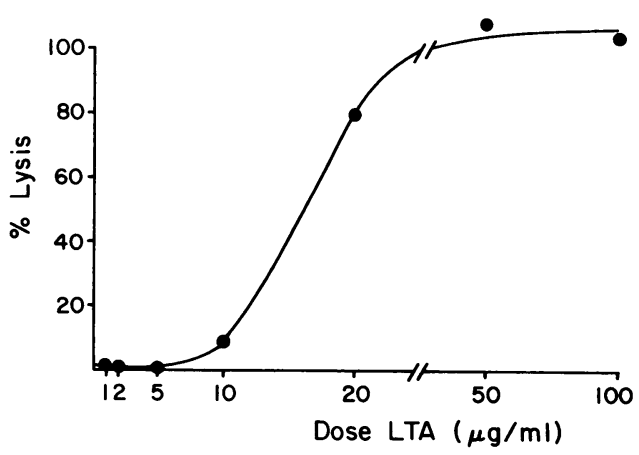

Figure 1. Specific lysis of rat E sensitized with varying doses of LTA. $\mathrm{E}$ at a concentration of $5.4 \times 10^{8}$ cells $/ \mathrm{ml}$ of $\mathrm{VBS}^{++}$were incubated at $37^{\circ} \mathrm{C}$ for 30 min with the desired amount of LTA or buffer, washed in $\mathrm{GVB}^{++}$, and then incubated at a concentration of $4.5 \times 10^{7}$ cells $/ \mathrm{ml}$ with $50 \%$ autologous $\mathrm{NRS}^{\text {in }} \mathrm{GVB}^{++}$for $30 \mathrm{~min}$ at $37^{\circ} \mathrm{C}$. There was no significant lysis of control $\mathrm{E}$. 


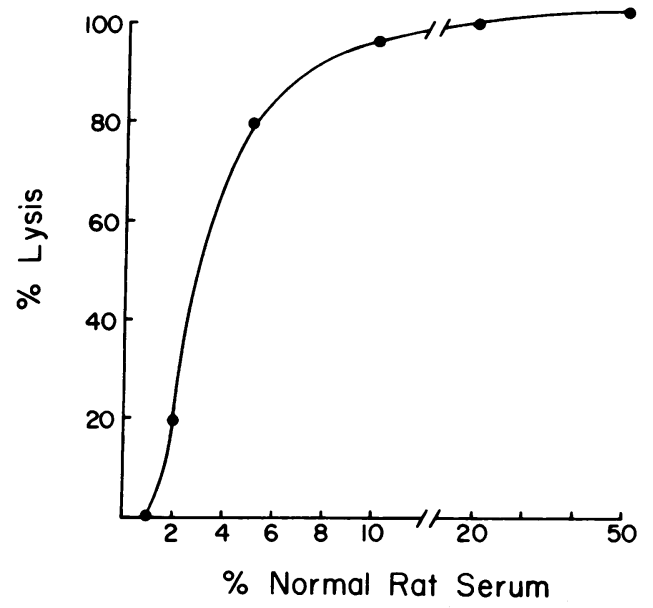

Figure 2. Specific lysis of rat LTA-E in increasing concentrations of autologous NRS. E at a concentration of $5.4 \times 10^{8}$ cells $/ \mathrm{ml}$ of $\mathrm{VBS}^{++}$ were incubated at $37^{\circ} \mathrm{C}$ for $30 \mathrm{~min}$ with $50 \mu \mathrm{g} / \mathrm{ml} \mathrm{LTA}$ or buffer, washed in $\mathrm{GVB}^{++}$, and then incubated at a concentration of $4.5 \times 10^{7}$ cells $/ \mathrm{ml}$ with the desired concentration of serum for $30 \mathrm{~min}$ at $37^{\circ} \mathrm{C}$. Lysis of control erythrocytes did not exceed 3\%.

NRS diluted in $\mathrm{GVB}^{++}$resulted in $\mathbf{9 2 . 9 \%}$ net lysis. Similarly, human E optimally sensitized with $50 \mu \mathrm{g} / \mathrm{ml}$ LTA did not lyse when these cells were incubated in 50\% autologous normal human serum (NHS) diluted in GVB-Mg-EGTA, whereas $100 \%$ lysis was observed when these cells were incubated in $50 \%$ autologous serum in $\mathrm{GVB}^{++}$(Table I). These results were reproducible even when the time of incubation in serum was increased from 30 to $60 \mathrm{~min}$. To confirm that alternative pathway activation could occur under the above conditions, rabbit $\mathrm{E}$ were incubated at a concentration of $4.5 \times 10^{7}$ cells $/ \mathrm{ml}$ in $50 \% \mathrm{NRS}$ which had been diluted in GVB-Mg-EGTA. After incubation at $37^{\circ} \mathrm{C}$ for $30 \mathrm{~min}, 100 \%$ lysis of the $\mathrm{E}$ was observed.

The ability of LTA to sensitize autologous $E$ for lysis via the alternative pathway was also examined using autologous $\mathrm{E}$ in either C2D HS or C4D GPS. As can be seen in Table I, incubation of LTA-sensitized C2D human E in 50\% autologous C2D HS resulted in $72.5 \%$ lysis. Similarly, incubation of LTA-sensitized C4D guinea pig $\mathrm{E}$ in 50\% autologous C4D GPS resulted in $30.9 \%$ lysis. The lysis of guinea pig E presensitized with varying

Table I. Role of the Alternative Pathway in the Lysis of Autologous LTA-E

\begin{tabular}{lc}
\hline Erythrocyte/autologous serum & $\begin{array}{l}\text { Specific } \\
\text { lysis }\end{array}$ \\
\hline & $\%$ \\
Rat LTA-E/NRS & 92.9 \\
Rat LTA-E/NRS in GVB-Mg-EGTA & 0.0 \\
Normal human LTA-E/NHS & 96.7 \\
Normal human LTA-E/NHS in GVB-Mg-EDTA & 0.0 \\
C2D human LTA-E/C2D HS & 72.5 \\
C4D guinea pig LTA-E/C4D GPS & 30.9 \\
\hline
\end{tabular}

E were incubated in the presence or absence of optimal amounts of LTA, washed, then resuspended in autologous serum. Lysis was determined spectrophotometrically after incubation for $30 \mathrm{~min}$ at $37^{\circ} \mathrm{C}$. doses of LTA was also examined in both autologous C4D GPS and C4D GPS containing $500 \mathrm{U} / \mathrm{ml}$ of purified guinea pig C4 (Fig. 3). While dose-dependent lysis was observed in the autologous C4D GPS, lysis of the same cells was markedly enhanced in autologous C4D GPS containing added C4.

Additional experiments were performed in order to examine the apparent discrepancy between the use of EGTA and the use of either C2D HS or C4D GPS to test the ability of LTA-E to by lysed in autologous serum via the alternative pathway. Incubation of optimally sensitized rat LTA-E $(50 \mu \mathrm{g} / \mathrm{ml}$ of LTA) in $50 \%$ autologous NRS diluted in GVB-Mg-EGTA gave only $8.4 \%$ consumption of $\mathrm{C} 3(17)$, indicating that there was no activation of the alternative pathway. In contrast, rat LTA-E incubated in 50\% autologous NRS diluted in $\mathrm{GVB}^{++}$consumed $31 \%$ of the $\mathrm{C} 3$. In addition, optimally sensitized human LTAE $(50 \mu \mathrm{g} / \mathrm{ml}$ of LTA) were not lysed in $50 \%$ rat serum which had been diluted in GVB-Mg-EGTA, indicating that the EGTA also inhibited lysis of heterologous LTA-E via the alternative pathway. Finally, experiments were performed in order to determine if treatment of the LTA-E with EGTA removed the LTA and, thereby, interfered with alternative pathway activation. When rat E were optimally sensitized with $50 \mu \mathrm{g} / \mathrm{ml}$ of radiolabeled LTA and then treated with GVB-Mg-EGTA, none of the radiolabeled LTA was removed.

In vivo clearance of autologous LTA-E. The following experiments were performed to determine whether complement activation could result in lysis and/or clearance of autologous LTA-E in vivo. Groups of rats were injected intravenously with either buffer-treated autologous ${ }^{51} \mathrm{Cr}$-labeled $\mathrm{E}$ or with autologous ${ }^{51} \mathrm{Cr}$-labeled $\mathrm{E}$ that had been sensitized in vitro with $50 \mu \mathrm{g} / \mathrm{ml}$ LTA. As can be seen in Fig. 4, the control animals demonstrated normal survival of the autologous buffer-treated E (93.6\%). In contrast, there was a rapid disappearance of the reinfused cells in the animals that received autologous LTA-E, with an average of only $2.9 \%$ remaining in the circulation after $10 \mathrm{~min}(P$ $<0.001$ ). Intravascular hemolysis appeared to be responsible in large part for the disappearance of the LTA-E, as judged by the appearance of significant amounts of ${ }^{51} \mathrm{Cr}$ in the plasma as early as 2 min after injection (Fig. 5).

When a similar group of animals was pretreated with CoVF, in order to deplete them of functional $\mathrm{C} 3$, the intravascular sur-

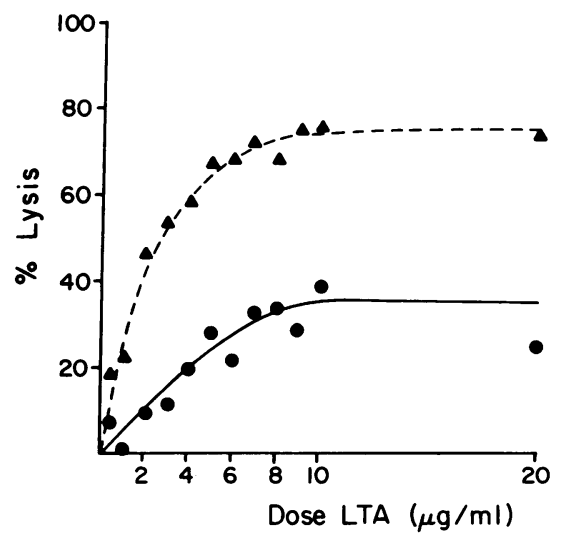

Figure 3. Specific lysis of LTA-E from a C4-deficient guinea pig in $50 \%$ autologous C4D GPS (•) or 50\% autologous C4D GPS containing $500 \mathrm{U} / \mathrm{ml}$ of purified guinea pig $\mathrm{C4}(\triangle)$. The protocol is the same as that described in Fig. 1. There was no significant lysis of control E. 


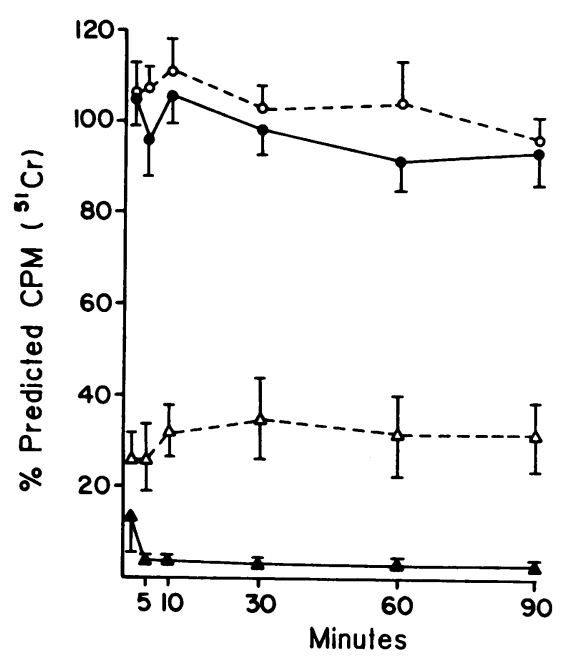

Figure 4. Survival of ${ }^{51} \mathrm{Cr}$-labeled rat $\mathrm{E}$ at intervals of time after infusion into autologous animals: $\mathrm{E}$ in normal rats $(\bullet)(n=6), \mathrm{E}$ in CoVFtreated rats $(0)(n=4)$, LTA-E in normal rats $(\Delta)(n=6)$, and LTA-E in CoVF-treated rats $(\Delta)(n=5)$. After a total volume of $0.5 \mathrm{ml}$ of labeled $\mathrm{E}$ was injected i.v. into each recipient animal, $0.1-\mathrm{ml}$ aliquots of blood were withdrawn at each time point, and the amount of ${ }^{51} \mathrm{Cr}$ present in the $\mathrm{E}$ fraction determined. Results were expressed as the mean percent predicted counts per minute $( \pm \mathrm{SE})$ based upon the dilution of total injected counts per minute into the blood volume of each animal.

vival of autologous LTA-E was markedly improved when compared with the survival of autologous LTA-E in normal animals $(P<0.01)$ (Fig. 4). The E clearance observed in this complementdeficient group was not accounted for by intravascular hemolysis, as judged by the absence of ${ }^{51} \mathrm{Cr}$ counts from the plasma samples (Fig. 5).

Serum antibody to the LTA was detectable in all rats with $\mathrm{AH}_{50}$ titers ranging from $1 / 29$ to $1 / 168$.

Organ sequestration of autologous LTA-E. To examine the role of organ sequestration in the diminished survival of autol-

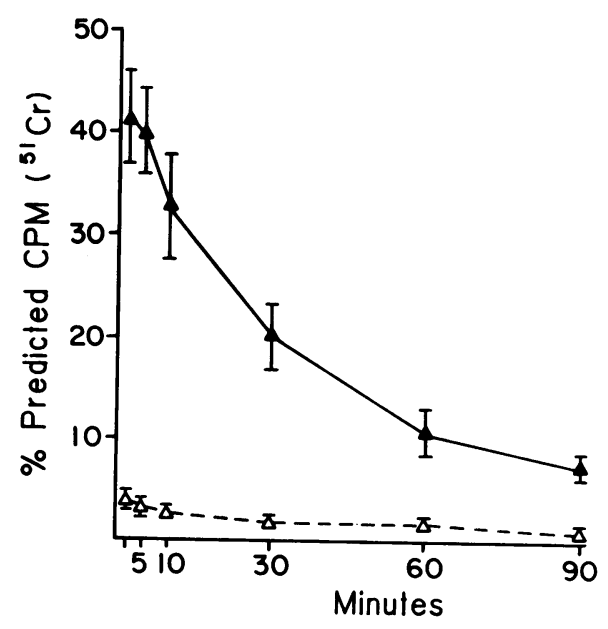

Figure 5. Presence of free ${ }^{51} \mathrm{Cr}$ in the plasma fractions of aliquots of blood withdrawn at intervals of time after injection of LTA-E into autologous normal rats $(\Delta)(n=6)$ or CoVF-treated rats $(\Delta)(n=5)$. The protocol is the same as that described in the legend to Fig. 4. Results are expressed as mean percent predicted counts per minute ( $\pm \mathrm{SE})$. ogous LTA-E, normocomplementemic rats and rats depleted of complement by CoVF treatment were killed $30 \mathrm{~min}$ after the infusion of their autologous LTA-sensitized ${ }^{51} \mathrm{Cr}$-labeled E, and a comparison of total organ counts was made between the two groups. Normal rats and CoVF-treated rats receiving autologous unsensitized ${ }^{51} \mathrm{Cr}$-labeled $\mathrm{E}$ were also included as controls. As can be seen in Table II, $66.4 \%$ of the total injected ${ }^{51} \mathrm{Cr}$ activity could be recovered in the livers of the complement-depleted rats that had received autologous LTA-E. The liver tissue of normal rats receiving autologous LTA-E contained $26.1 \%$ of the total injected counts. This is noteworthy, because, although this group displayed evidence of intravascular hemolysis of injected cells as described earlier, only $41.5 \%$ of the total injected ${ }^{51} \mathrm{Cr}$ activity was found free in the plasma at 2 min after injection, with diminishing amounts recoverable thereafter (Fig. 5). Only 5.8\% of the total injected counts were recovered in the liver tissue removed from each of the normal and complement-depleted groups receiving unsensitized autologous E. Liver sequestration of $E$ appeared to be irreversible, inasmuch as no increase in circulating labeled $\mathrm{E}$ could be detected $24 \mathrm{~h}$ after infusion.

\section{Discussion}

The membrane LTA of gram-positive bacteria possess certain characteristics which may be important in the interaction of the bacterium and the host during the course of an infection. They are shed by viable organisms under physiologic conditions and may then bind spontaneously to the surfaces of mammalian cells. Once attached to the cell surface, they retain their antigenic properties (9-12) and can also activate the complement system in heterologous sera $(12,13)$. While the binding of LTA to a variety of mammalian cell types has been well studied (5-8) and the direct cytotoxic potential of LTA appears to be low (24), the consequences of an interaction of the cell-bound LTA with the immune system of the host have not been addressed. The present study examined the potential role of LTA-induced complement activation in mediating damage to autologous mammalian host cells during bacterial infections.

Previous studies have shown that E bearing surface LTA are susceptible to lysis by activation of the classical and/or alternative pathways of complement in heterologous sera (11-13). However, there have been no studies to determine whether LTA-E are susceptible to attack by autologous complement. This is important in view of recent reports that antibody-sensitized $\mathrm{E}$ are relatively resistant to lysis by complement obtained from an homologous source $(25,26)$. Strictly autologous conditions were

Table II. Sequestration of Autologous $E$

\begin{tabular}{lclll}
\hline & \multicolumn{2}{l}{ Organ } & & \\
\cline { 2 - 5 } Condition & Liver & Spleen & Lung & Kidney \\
\hline Normal rat/E & $5.8(1.0)$ & $1.2(0.1) \ddagger$ & $1.4(0.2)$ & $1.2(0.2)$ \\
Normal rat/LTA-E & $26.1(2.8)^{*}$ & $3.0(0.4) \ddagger$ & $0.9(0.2)$ & $4.3(2.5)$ \\
CoVF rat/E & $5.8(0.2)$ & $1.2(0.1) \ddagger$ & $1.6(0.1)$ & $1.3(0.1)$ \\
CoVF rat/LTA-E & $66.5(4.1)^{*}$ & $4.0(0.6) \ddagger$ & $1.5(0.4)$ & $0.5(0.1)$ \\
& & & & \\
\hline
\end{tabular}

${ }^{51} \mathrm{Cr}$-labeled $\mathrm{E}$ were injected into autologous rats and whole-organ counts per minute were determined after $30 \mathrm{~min}$. Results are expressed as percent total injected counts per minute.

$* P<0.001$.

$\ddagger P<0.01$. 
used in this study to approximate the environment which a host cell would encounter during the course of a natural infection.

Lysis of rat LTA-E was observed upon their exposure to autologous serum in vitro, indicating that LTA is capable of modifying host cells for lysis by complement, even when the complement is obtained from an autologous source. Our experimental conditions were designed to maximize the potential for autologous cell lysis by using adequate doses of bacterial LTA and relatively high concentrations of autologous serum. Presumably, the binding of an adequate density of LTA to the mammalian cell surface was sufficient to bypass any inhibitory influences and resulted in autologous complement activation in a host cell-directed fashion. The requirement of complement activation for lysis of autologous cells was verified by demonstrating that lysis was inhibited by treating the serum with EDTA, heat, or CoVF.

The ability of LTA to sensitize E for activation of the alternative pathway under autologous conditions was examined by incubating LTA-E obtained from either a C4-deficient guinea pig or from a C2-deficient patient in their respective autologous sera. Lysis of the $\mathrm{E}$ was observed in each case, demonstrating that LTA can induce complement-mediated cell lysis in the absence of an intact classical pathway. However, lysis is clearly facilitated by an intact classical pathway because the lysis of LTA-E in autologous C4D GPS was significantly enhanced when C4 was added to the serum.

A role for the alternative pathway in mediating the lysis of LTA-E could not be demonstrated when the corresponding autologous sera were treated with EGTA in order to inhibit the classical pathway. There was no evidence that the complement system was being activated in the presence of EGTA even though lysis did not occur, not was there evidence that the EGTA was responsible for removing LTA from the E surface. The EGTAtreated sera were able to support the lysis of rabbit $\mathrm{E}$, demonstrating an intact alternative pathway, at least with respect to rabbit $\mathrm{E}$. Rabbit $\mathrm{E}$ are known to be potent activators of the alternative pathway in heterologous sera. However, the lysis of rabbit $\mathrm{E}$ in heterologous EGTA-treated sera may not necessarily indicate that the alternative pathway is intact with respect to less potent activating stimuli in autologous systems. Moreover, preferential inhibition of the alternative pathway by homologous, but not heterologous, complement has been demonstrated (26). The results of the present study suggest that serum deficient in a classical pathway component on a genetic basis may provide a more sensitive means of assessing the role of the autologous alternative pathway in mediating the destruction of LTA-bearing cells.

The current studies did not examine the potential role of antibody in the lysis of LTA-E by autologous complement. We did try a number of different experimental approaches aimed at studying the participation of antibody in the lytic system, but none were successful because of technical limitations. For example, we examined a large number of germ-free rats for serum antibody to LTA, but unfortunately they all had significant levels of anti-LTA antibody in their serum. In addition, we also attempted to absorb NRS with unencapsulated pneumococci at $0^{\circ} \mathrm{C}$ in an attempt to remove anti-LTA antibody but that also diminished the amount of hemolytic complement in the serum.

When rat LTA-E were reinfused into normal autologous donor animals, they underwent rapid intravascular hemolysis. The circulatory survival of LTA-E was greater in the complementdepleted rats than that observed in the normocomplementemic rats, but was nevertheless diminished in comparison with the survival of control E. While complement-mediated lysis was responsible for the intravascular destruction of the autologous LTA-E in normal rats, animals depleted of functional complement by pretreatment with CoVF did not exhibit any detectable lysis of their reinfused cells. Rather, sequestration of sensitized $E$ in the hepatic tissue of recipient animals accounted for their disappearance in the complement-depleted animals.

The mechanism resonsible for the hepatic sequestration of autologous LTA-E in the CoVF-treated animals is not clear. Such sequestration might have resulted from clearance of antibody-coated cells by the hepatic reticuloendothelial system of the host. In fact, anti-LTA antibody was readily detectable in all the rats tested. Alternatively, the LTA-E might have interacted with the host hepatic tissue on the basis of altered surface charge or carbohydrate content. Finally, recent studies have shown that the small amount of $\mathrm{C} 3$ which remains after CoVF treatment may be adequate enough to mediate clearance of desialidated $E$ by the reticuloendothelial system even though the levels are not sufficient to support lysis (27). Thus, the low levels of C3 which remained in the CoVF-treated animals in the current experiments may have been responsible for the clearance of the LTA-E.

The current studies were performed using $E$ as target cells. E were chosen as target cells because they would serve as a convenient general model of the interaction of LTA, host cells, and complement. They are easily obtained from a single animal, conveniently labeled in vitro, and are susceptible to complementmediated lysis. In addition, they can be reinfused into the same animal from which they were obtained, and their in vivo destruction can be determined. It is also possible that LTA fixed to the surface of nucleated cells could act to induce damage by autologous complement. In fact, complement-mediated damage to LTA-sensitized nucleated cells may be more biologically relevant to the situation existing in natural bacterial infections than is complement-mediated damage to LTA-E.

These data demonstrate that complement-mediated host cell destruction can occur both in vitro and in vivo as a result of the fixation of LTA to the cell surface. It is possible that this mechanism of host cell damage is operative during the course of natural bacterial infections. Presumably, LTA released locally by gram-positive bacteria would bind to host cells, where it could then interact with antibody and/or autologous complement resulting in host cell destruction. While the presence of anti-LTA antibody would favor damage via activation of the classical pathway, cell damage might also occur in the nonimmune host via activation of the alternative pathway.

\section{Acknowledgments}

We are grateful for the expert technical assistance of Andrea J. Swift and to Gail N. Smith for preparation of the manuscript.

\section{References}

1. Wicken, A. J., and K. W. Knox. 1975. Lipoteichoic acids: a new class of bacterial antigen. Science (Wash. DC). 187:1161-1167.

2. Shockman, G. D. 1981. Cellular localization, excretion, and physiological roles of lipoteichoic acid in gram-positive bacteria. In Chemistry and Biological Activities of Bacterial Surface Amphiphiles. G. D. Shockman and A. J. Wicken, editors. Academic Press, Inc., New York. 2140.

3. Alkan, M. L., and E. H. Beachey. 1978. Excretion of lipoteichoic 
acid by group A streptococci: influence of penicillin on excretion and loss of ability to adhere to human oral mucosal cells. J. Clin. Invest. 61: 671-677.

4. Utsui, Y., A. Oitya, Y. Takenouchi, M. Tajima, and S. Sugawara. 1983. Release of lipoteichoic acid from Staphylococcus aureus by treatment with cefmetazole and other $\beta$-lactam antibiotics. J. Antibiot. (Tokyo). 36:1380-1386.

5. Beachey, E. H., J. B. Dale, W. A. Simpson, J. D. Evans, K. W. Knox, I. Ofek, and A. J. Wicken. 1979. Erythrocyte binding properties of streptococcal lipoteichoic acids. Infect. Immun. 23:618-625.

6. Beachey, E. H., T. M. Chiang, I. Ofek, and H. H. Kang. 1977. Interaction of lipoteichoic acid of group A streptococci with human platelets. Infect. Immun. 16:649-654.

7. Beachey, E. H., J. B. Dale, S. Grebe, A. Ahmed, W. A. Simpson, and I. Ofek. 1979. Lymphocyte binding and T-cell mitogenic properties of group A streptococcal lipoteichoic acid. J. Immunol. 122:189-195.

8. Simpson, W. A., I. Ofek, C. Sarasohn, J. C. Morrison, and E. H. Beachey. 1980. Characteristics of the binding of streptococcal lipoteichoic acid to human oral epithelial cells. J. Infect. Dis. 141:457-462.

9. Rantz, L. A., E. Randall, and A. Zuckerman. 1956. Hemolysis and hemagglutination by normal and immune sera of erythrocytes treated with a nonspecies specific bacterial substance. J. Infect. Dis. 98:211-222.

10. Harris, T. N., and S. Harris. 1953. Agglutination by human sera of erythrocytes incubated with streptococcal culture concentrates. $J$. Bacteriol. 66:159-165.

11. Neter, E. 1956. Bacterial hemagglutination and hemolysis. Bacteriol. Rev. 20:166-188.

12. Hummell, D. S., A. J. Swift, A. Tomasz, and J. A. Winkelstein. 1985. Activation of the alternative complement pathway by pneumococcal lipoteichoic acid. Infect. Immun. 47:384-387.

13. Rantz, L. A., A. Zuckerman, and E. Randall. 1952. Hemolysis of red blood cells treated by bacterial filtrates in the presence of serum and complement. J. Lab. Clin. Med. 39:443-448.

14. Mayer, M. M. 1961. Complement and complement fixation. In Experimental Immunochemistry. 2nd edition. E. A. Kabat and M. M. Mayer, editors. Charles C Thomas, Springfield, IL. 133-240.

15. Coonrod, J. D., and S. D. Jenkins. 1979. Functional assay of the alternative complement pathway of rat serum. J. Immunol. Methods. 31:291-301.
16. Hirsch, R. L., J. A. Winkelstein, and D. E. Griffin. 1980. The role of complement in viral infections. III. Activation of the classical and alternative complement pathways by Sindbis virus. J. Immunol. 124:2507-2510.

17. Shin, H. S., and M. M. Mayer. 1968. The third component of the guinea pig complement system. II. Kinetic study of the reaction of EAC4,2a with guinea pig C3. Biochemistry. 7:2997-3002.

18. Ellman, L., I. Green, and M. M. Frank. 1970. Genetically controlled complete deficiency of the fourth component of complement in the guinea pig. Science (Wash. DC). 170:74-75.

19. Hyatt, A. C., K. M. Altenburger, R. B. Johnston, Jr., and J. A. Winkelstein. 1981. Increased susceptibility to severe pyogenic infections in patients with an inherited deficiency of the second component of complement. J. Pediatr. 98:417-419.

20. Smith, M. R., and W. B. Wood, Jr. 1969. Heat-labile opsonins to pneumococcus. I. Participation of complement. J. Exp. Med. 130: 1209-1227.

21. Tomasz, A. 1970. Cellular metabolism in genetic transformation of pneumococci: requirement for protein synthesis during induction of competence. J. Bacteriol. 101:860-867.

22. Briles, E. B., and A. Tomasz. 1972. Pneumococcal Forssman antigen: a choline-containing lipoteichoic acid. J. Biol. Chem. 248:63946397.

23. Baker, J. H. I., J. R. Lindsay, and S. H. Weisbroth, editors. 1979. The Laboratory Rat. Academic Press, Inc., New York. Vol. II: Appendix.

24. Leon, O., and C. Panos. 1983. Cytotoxicity and inhibition of normal collagen synthesis in mouse fibroblasts by lipoteichoic acid from Streptococcus pyogenes type 12. Infect. Immun. 40:785-794.

25. Houle, J. J., and E. M. Hoffman. 1984. Evidence for the restriction of the ability of complement to lyse homologous erythrocytes. J. Immunol. 133:1444-1452.

26. Okada, H., H. Tanka, and N. Okada. 1983. Prevention of complement activation on the homologous cell membrane of nucleated cells as well as erythrocytes. Eur. J. Immunol. 13:340-344.

27. Brown, E. J., K. A. Joiner, and M. M. Frank. 1983. Interaction of desialated guinea pig erythrocytes with the classical and alternative pathways of guinea pig complement in vivo and in vitro. J. Clin. Invest. 71:1710-1719. 